\title{
Administracyjnoprawny obowiązek szczepienia dzieci a zgoda przedstawiciela ustawowego na badania kwalifikacyjne ${ }^{1}$
}

\section{Wprowadzenie}

Zagadnienia pojawiające się na styku prawa publicznego i prywatnego od lat zajmują prawników. Różne metody regulacji oraz inne spojrzenie na prawo obfitują niejednokrotnie w zasadniczo odmienne rozumienie tych samych instytucji i zjawisk stanowiących przedmiot zainteresowania ustawodawcy. Przyjmując jednak racjonalność jego działań oraz pełną wiedzę na temat tego, $\mathrm{w}$ jakich realiach jest stosowane stanowione przez niego prawo, w sytuacjach mających miejsce $\mathrm{w}$ ramach materii regulowanych prawem publicznym i prywatnym szukać należy wykładni, która doprowadzi do wyników najbardziej odpowiadających pierwotnej intencji i celowi, który ustawodawca chciał osiągnać. Pozostawienie organom i podmiotom stosującym prawo pewnej swobody decyzji pozwala dostosować obowiązujące normy do realnych potrzeb podmiotów, którym normy te mają służyć. Niekiedy jest i tak, że interesy, które ustawodawca chce zabezpieczyć w ramach właściwego dla prawa publicznego przymusu i obowiązku, pozostają w istocie bądź pozornie w sprzeczności z możliwością podejmowania decyzji w ramach właściwej prawu prywatnemu autonomii jednostki.

${ }^{1}$ Artykuł został przygotowany w ramach realizacji grantu „Małoletni wobec rodziców i państwa. Współczesne, polskie uwarunkowania prawne realizacji zasady dobra dziecka oraz partycypacji" (umowa z NCN nr UMO-2015/19/B/HS5/03014). 
Przykładem, który dobrze ilustruje powyższe, jest sytuacja obowiązkowych szczepień, w szczególności gdy chodzi o dzieci. Szczepienia te sa przewidziane przez ustawodawcę $\mathrm{w}$ Ustawie $\mathrm{z}$ dnia 5 grudnia 2008 r. o zapobieganiu oraz zwalczaniu zakażeń i chorób zakaźnych u ludzi $i^{2}$. W ramach prezentowanych rozważań poruszony zostanie aspekt uprawnienia przedstawicieli ustawowych do podejmowania decyzji w sprawach dziecka w związku z dokonaniem szczepienia. Problem jest obecnie szeroko dyskutowany także w środkach społecznego przekazu $^{3}$. Stanowi jednak od dawna przedmiot zainteresowania doktryny i orzecznictwa ${ }^{4}$.

${ }^{2}$ Ustawa dnia 5 XII 2008 r. o zapobieganiu oraz zwalczaniu zakażeń i chorób zakaźnych u ludzi (Dz.U. Nr 234, poz. 1570 ze zm.), dalej „u.z.z.c.z.”.

${ }^{3}$ I. Filc-Redlińska, Szczepionki. Nie daj się zwariować, Kraków 2016; A. Sosnowska, Czy szczepić dziecko?, http://dziecisawazne.pl/czy-szczepic-dzieci/ (dostęp: 16 V 2017); Forum dla rodziców: Nie szczepimy, http://szczepienia.org.pl/index.php (dostęp: 16 V 2017); strona Ogólnopolskiego Stowarzyszenia Wiedzy o Szczepieniach „STOP NOP", http://www.stopnop.pl/ (dostęp: 16 V 2017), także strona tego stowarzyszenia na Facebooku; Prawne konsekwencje nieszczepienia dzieci, http://dziecisawazne.pl/nieszczepienie-dzieci/ (dostęp: 17 V 2017); program Przegląd prasy. Przed sąd za nieszczepienie dziecka, 19 V 2017, http://www.tvn24.pl/wiadomosci-z-kraju,3/za-nieszczepieniedziecka-grozi-kurator-badz-odebranie-dziecka,741291.html; Sad za brak szczepionki. Rodzicom grozi odebranie dziecka, http://wyborcza.pl/TylkoZdrowie/7,137474,21899265, sad-za-brak-szczepionki-rodzicom-grozi-nawet-odebranie-dziecka.html\#BoxGWImg (dostęp: 2 VI 2017).

${ }^{4}$ J. Zajdel, Prawo w medycynie, Łódź 2006, passim; J. Sawicki, Przymus leczenia, eksperyment, udzielanie pomocy i przeszczep w świetle prawa, Warszawa 1966; A. Dobrzańska, Dzieci maja prawo do zdrowia, "Medycyna Praktyczna. Szczepienia” 2012, nr 2; M. Mikos, Dokumentacja medyczna w zakresie szczepień ochronnych, w: Dokumentacja medyczna, pod red. P. Pochopnia, Warszawa 2012, passim; I. Jaworska, Odmowa zaszczepienia dziecka i jej konsekwencje prawne, "Przegląd Prawa Publicznego" 2017, nr 3, s. 60-72; M. Serwach, Obowiązkowe szczepienia ochronne, http://gazetalekarska.pl/?p=17117 (dostęp: 18 V 2017). Z najnowszego orzecznictwa wyrok Naczelnego Sądu Administracyjnego (NSA) z 6 XII 2016 r., sygn. II OSK 812/15; wyrok Wojewódzkiego Sądu Administracyjnego (WSA) w Warszawie z 19 X 2016 r., sygn. VII SA/Wa 2540/15; wyrok WSA w Warszawie z 27 VII 2016 r., sygn. VII SA/Wa 2350/15; wyrok WSA w Warszawie z 27 VII 2016 r., sygn. VII SA/Wa 2351/15; wyrok WSA w Lublinie z 26 I 2016 r., sygn. III SA/Lu 1277/15; wyrok WSA w Olsztynie z 17 XII 2015 r., sygn. II SA/Ol 860/15; wyrok WSA w Poznaniu z 2 XII 2015 r., sygn. II SA/Po 829/15; wyroki WSA w Lublinie: z 19 XI 2015 r., sygn. III SA/Lu 222/15; z 19 XI 2015 r., sygn. SA/Lu223/15; z 17 III 2016 r., sygn. III SA/Lu 936/15; wyroki WSA we Wrocławiu: z 4 XI 2015 r., sygn. IV SA/Wr 90/15; z 4 XI 2015 r., sygn. IV SA/Wr 91/15; z 4 XI 2015 r., sygn. IV SA/Wr 89/15; z 12 VI 2015 r., sygn. III SA/Wr 197/15; z 12 VI 2015 r., sygn. III SA/Wr 198/15; wyrok WSA w Gorzowie Wielkopolskim z 9 IX 2015 r., sygn. II SA/Go 331/15; wyrok WSA w Białymstoku z 16 IV 2013 r., sygn. II SA/Bk 18/13; wszystkie wyroki dostępne na stronie http://orzeczenia.nsa.gov.pl. 
Nie ulega wątpliwości, że ustawodawca, przyjmując w ustawie o zapobieganiu oraz zwalczaniu zakażeń i chorób zakaźnych u ludzi obowiązek szczepień ochronnych, realizuje i zabezpiecza interes publiczny. Interes ten objawia się osiągnięciem stanu określanego jako zdrowie publiczne ${ }^{5}$. Przyjmuje się bowiem następujące założenie: nałożenie na obywateli przejściowej niedogodności związanej z poddaniem się szczepieniom ochronnym czy innym działaniom przewidzianym w ustawie w ogólnym bilansie zdrowia publicznego będzie korzystniejsze zarówno dla wszystkich obywateli, jak i dla każdego z tych, którzy obowiązek w danym momencie swojego życia powinni zrealizować. Zastosowanie szczepień ochronnych zmniejszy lub wyeliminuje niebezpieczeństwo zapadnięcia w przyszłości na chorobę zakaźna, której skutki mogłyby być dotkliwe nie tylko dla osoby, która szczepieniu się nie poddała, ale i dla innych obywateli. Przyjmuje się w tym zakresie konstrukcję obowiązku, któremu podlegają wszyscy obywatele. Jest to podyktowane wspólnym interesem wszystkich podlegających danemu ustawodawstwu, nie zaś chęcią dokuczenia czy uprzykrzenia życia poszczególnym podmiotom.

Pojawia się jednak pytanie o dopuszczalność wyrażenia zgody na działania zmierzające do wykonania obowiązku. Innymi słowy, chodzi o rozstrzygnięcie, czy mimo nałożonego przez ustawodawcę obowiązku można zdecydować o niepoddaniu się bądź niepoddaniu innej osoby szczepieniu i czy mieści się to $\mathrm{w}$ granicach autonomii jednostki ${ }^{6}$. Istotna będzie w tym zakresie zwłaszcza decyzja przedstawiciela ustawowego

${ }^{5}$ Należy zauważyć, że Konstytucja nie posługuje się określeniem „zdrowie publiczne”. Można jednak przyjąć, że jest ono uszczegółowieniem konstytucyjnej kategorii „zdrowia". Jest to istotne w kontekście dopuszczalności ograniczenia wolności i autonomii jednostki z powołaniem się na tę kategorię dobra ograniczającego jednostkę w swoich wyborach i decyzjach. Uzasadnienia dla tego ograniczenia szukać można w konstytucyjnej przesłance "praw i wolności innych osób” oraz "zdrowia” rozumianego jako dobro indywidualne. Można zgodzić się z argumentacją, że przyjęcie takich założeń (ochrona dóbr indywidualnych) w większym stopniu uzasadnia poszanowanie wolności i praw jednostki oraz usprawiedliwia stosowany wobec niej przymus niż kategoria zdrowia publicznego, która może być bardziej podatna na ryzyko rozszerzającej i niejednolitej interpretacji czy też pozwalać organom władz publicznych na większą dowolność działania (w tym stosowania środków przymusu) oraz w większym stopniu podporządkowywać jednostkę organom władzy publicznej.

${ }^{6}$ Za zwrócenie uwagi na ten aspekt zagadnienia dziękuję Piotrowi Walęckiemu, studentowi IV roku Wydziału Prawa i Administracji UAM w Poznaniu, seminarzyście w Katedrze Prawa Cywilnego, Handlowego i Ubezpieczeniowego; prezentacja w ramach seminarium magisterskiego, niepublikowane. 
decydującego o sytuacji faktycznej małoletniego dziecka. Celem niniejszych rozważań jest zatem próba udzielenia odpowiedzi na pytanie o charakter ewentualnej odmowy zgody na wykonanie szczepień ochronnych u dzieci. Jednocześnie należy zauważyć, że poza zakresem rozważań pozostaną kwestie natury medycznej, w szczególności zaś poszukiwanie rozstrzygnięcia dylematu, czy szczepionki "są dobre" czy "złe"7.

Istotą rozważań będzie analiza sytuacji rodziców (przedstawicieli ustawowych dziecka) zobowiązanych do uczynienia zadość realizacji obowiązku zaszczepienia małoletniego wówczas, gdy uznają oni, że obowiązek ten godzi w podstawową zasadę, jaką jest zasada dobra dziecka. Główny nurt problemu sprowadza się do udzielenia odpowiedzi na pytanie, jak traktować stanowisko rodziców (przedstawicieli ustawowych), którzy powołując się na zasadę autonomii, uprawnienie wynikające z władzy rodzicielskiej, w szczególności obowiązek pieczy nad osobą małoletniego i jego reprezentację, nie podejmują działań zmierzających do realizacji obowiązku nałożonego przez prawo. Często argumentacja przedstawicieli ustawowych sprowadza się do podkreślenia zasady dobra dziecka i tego, że dokonanie szczepienia istotnie godzi w uznane przez nich wartości, takie jak autonomia, wolność podejmowania decyzji dotyczących sytuacji faktycznej i prawnej dziecka czy wreszcie jego dobro. Pierwsza intuicja w ocenie problemu nakazuje przyjąć dwie odmienne próby rozstrzygnięcia zarysowanych wyżej dylematów. Po pierwsze, należy zwrócić uwagę na problem autonomii rodziców (przedstawicieli ustawowych), po drugie zaś na realizację zasady dobra dziecka. W drugim z przedstawionych stanowisk przyjmuje się, a przynajmniej czynią to przedstawiciele ustawowi, że szczepionka jest szkodliwa dla dziecka i że "niewyrażenie” zgody na przeprowadzenie szczepienia jest realizacją zasady dobra dziecka.

W tym kontekście w szczególności przedmiotem analiz będzie ocena charakteru prawnego odmowy poddania szczepieniu dziecka ze strony

\footnotetext{
${ }^{7}$ Należy tu podkreślić, że przyjmowana przez ustawodawcę konstrukcja obowiązkowego charakteru szczepienia ochronnego musi uwzględniać takie czynniki, jak śmiertelność choroby, waga i częstotliwość powikłań, zakaźność, skuteczność szczepionki czy jej bezpieczeństwo. Czynniki te nie wpływają bezpośrednio na sytuację jednostki poddawanej obowiązkowemu szczepieniu, ograniczając jej wolność i autonomię decyzyjną, niemniej jednak muszą być przez ustawodawcę brane pod uwagę. To ustawodawcy pozostawić należy ocenę w zakresie dopuszczalnego ograniczenia wolności i autonomii, z uwzględnieniem bilansu "zysków i strat” związanych z wyeliminowaniem choroby lub ograniczeniem zachorowalności przy jednoczesnym obowiązkowym i właściwie bezdyskusyjnym poddaniu obywateli dolegliwości w postaci szczepienia.
} 
przedstawiciela ustawowego. Pomijając zarysowane wyżej sposoby postrzegania problemu, istotne wydaje się także zwrócenie uwagi na dość nieprecyzyjne postanowienia ustawowe i ich wzajemną relację, zwłaszcza jeśli przywoła się wzmiankowany na wstępie rozważań styk aktów prawnych z dwóch różnych gałęzi prawa. Jak się wydaje, najważniejsza jawi się odpowiedź na pytanie: czy mimo nałożenia na jednostki obowiązku, którego wykonanie zostało zagrożone karą administracyjną, przedstawicielom ustawowym przysługuje na zasadach ogólnych uprawnienie do wyrażenia zgody na szczepienie ich dzieci bądź do decydowania na którymś z etapów tej procedury.

\section{Rola przedstawicieli ustawowych w kształtowaniu sytuacji faktycznej i prawnej dziecka}

Przedstawiciele ustawowi od chwili urodzenia aż do momentu osiągnięcia przez dziecko pełnoletności podejmują decyzje w zakresie możliwości wykonywania czynności diagnostycznych i terapeutycznych ${ }^{8}$. Biorąc pod uwagę fakt, że przedstawicielami ustawowymi w przeważającej mierze są rodzice dziecka, to im przypada prawo i obowiązek podejmowania decyzji w zakresie zdrowotnych losów dziecka. Rodzice podejmują te decyzje dlatego, że przysługuje im władza rodzicielska, ale też dlatego, że wiedza, co dla ich dziecka jest najlepsze.

Przepis art. $95 \S 1$ Kodeksu rodzinnego i opiekuńczego ${ }^{9}$ nakłada na rodziców obowiązek, a zarazem prawo do wykonywania pieczy nad osobą i majątkiem dziecka ${ }^{10}$. Na osobowe elementy pieczy rodziców w przypadku dziecka składać się będą działania faktyczne, które podejmowane są przez rodziców dla dobra dziecka, przy czym działania te nie stanowią elementu innych stosunków prawnych łączących rodziców z dziećmi. W dalszej kolejności składnikiem pieczy rodziców będą ich decyzje podejmowane w sytuacjach przewidzianych prawem ze względu

${ }^{8}$ Szerzej, także w odniesieniu do dziecka poczętego: J. Haberko, Cywilnoprawna ochrona dziecka poczętego a stosowanie procedur medycznych, Warszawa 2010, s. 97 i n. oraz literatura tam powołana.

${ }^{9}$ Ustawa z dnia 17 II 1964 r. - Kodeks rodzinny i opiekuńczy (tekst jedn. Dz.U. 2017, poz. 682), dalej "k.r.o.”.

${ }^{10}$ Z komentarzy zob. np. T. Sokołowski, Art. 95, w: Kodeks rodzinny i opiekuńczy. Komentarz, pod red. H. Doleckiego, T. Sokołowskiego, Warszawa 2013, s. 645 i n.; J. Ignatowicz, Art. 95, w: Kodeks rodzinny i opiekuńczy. Komentarz, pod red. K. Pietrzykowskiego, Warszawa 2012, s. 869 i n. 
na fakt małoletności dziecka, i to podejmowane w interesie dziecka, niemniej jednocześnie mające wpływ na jego sytuację prawną; wreszcie pieczę stanowić będzie obowiązek osobistej styczności z dzieckiem. Prezentowane elementy osobowe pieczy występować będą w stosunkach między rodzicami a dziećmi.

Rodzice, sprawując pieczę, mają kierować się zasadą dobra dziecka. Ustawodawca nie definiuje terminu "dobro dziecka”. W nauce zaproponowano kilka ujęć tego terminu. Według jednego ze stanowisk: „dobro dziecka oznacza kompleks wartości o charakterze materialnym i niematerialnym, niezbędnych do zapewnienia prawidłowego rozwoju fizycznego i duchowego dziecka oraz należytego przygotowania go do pracy (samodzielności życiowej) odpowiednio do jego uzdolnień, przy czym wartości te są zdeterminowane przez wiele różnorodnych czynników"11. W swoich rozważaniach T. Sokołowski przyjmuje natomiast, że dobro dziecka może być postrzegane zarówno jako pewna ceniona wartość, jak i jako pewien stan rzeczy ${ }^{12}$. W tym ujęciu dobro dziecka to „optymalna konfiguracja elementów dotyczącego dziecka stanu rzeczy, czyli interesu dziecka"13. Akcentuje się w doktrynie, że to właśnie dziecko jest najdonioślejszym i najważniejszym punktem odniesienia ocen, głównym adresatem i celem jakiegokolwiek postępowania medycznego oraz adresatem skutków na obszarze prawa cywilnego ${ }^{14}$. Dobro dziecka jest więc wartością wysoko cenioną przez ustawodawcę. Mamy z nią do czynienia zarówno w Konstytucji RP, jak i w innych aktach porządku krajowego i międzynarodowego, by wskazać jedynie Kodeks rodzinny i opiekuńczy czy Konwencję o prawach dziecka ${ }^{15}$; co więcej, ustawodawca zwykle daje pierwszeństwo dobru dziecka przed interesem rodziców ${ }^{16}$. Kierując się dobrem dziecka, rodzice powinni

${ }^{11}$ W. Stojanowska, Rozwód a dobro dziecka, Warszawa 1979, s. 21 i n.

12 T. Sokołowski, Władza rodzicielska nad dorastajacym dzieckiem, Poznań 1987, s. 10; idem, Problematyka AIDS w świetle prawa rodzinnego, Poznań 2000, s. 17 oraz powołana tam bogata literatura dotyczaca definiowania dobra dziecka.

${ }^{13}$ T. Sokołowski, Prawo rodzinne. Zarys wykładu, Poznań 2008, s. 13.

${ }^{14}$ T. Smyczyński, Aksjologiczne i prawne podstawy dopuszczalności wspomaganej prokreacji ludzkiej, w: Prawne, medyczne i psychologiczne aspekty wspomaganej prokreacji, pod red. J. Haberko, M. Łączkowskiej, Poznań 2005, s. 95.

${ }^{15}$ Konwencja o prawach dziecka przyjęta przez Zgromadzenie Ogólne Narodów Zjednoczonych w dniu 20 XI 1989 r. (Dz.U. 1991 Nr 120, poz. 526).

${ }^{16}$ W. Stojanowska, op. cit., s. 27; T. Smyczyński, op. cit., s. 95. Celem, dla którego realizuje się dobro dziecka, jest ochrona zarówno interesu dziecka, jak i interesu społecznego oraz interesu rodziców, zob. T. Sokołowski, Prawo rodzinne..., s. 123. 
dążyć do stworzenia dziecku korzystnej dla niego sytuacji życiowej, która będzie sprzyjać jego rozwojowi duchowemu i fizycznemu ${ }^{17}$.

W konsekwencji działania rodziców należy oceniać w świetle ochrony dobra dziecka i jego szczegółowych praw ułatwiających osiągnięcie dobra, o którym mowa. W literaturze nie jest kwestionowany pogląd, że takie wartości jak trwałość więzi małżeńskich i rodzinnych oraz dobro dziecka powinny być stawiane ponad wartościami dotyczącymi wyłącznie poszczególnych osób ${ }^{18}$. Nie sposób bowiem zaprzeczyć, iżby stanowisko takie nie znajdowało oparcia w wykładni systemowej prawa rodzinnego, w szczególności przepisów k.r.o., jak również na gruncie Konwencji o prawach dziecka ${ }^{19}$.

Rodzice pozostają w swych decyzjach mających za przedmiot osobę i sytuację dziecka pozostającego pod ich władzą rodzicielską autonomiczni. Ustawodawca darzy ich zaufaniem i decyduje się na ingerencję jedynie w sytuacji, w której dobro dziecka jest zagrożone ${ }^{20}$. Autonomia rodziców (przedstawicieli ustawowych) nie obejmuje jednak, jak się wydaje, wszystkich sfer życia dziecka. Owszem, rodzice mogą podejmować działania, poprzez które będą wychowywać i kształtować małoletniego, i czynić to wedle własnego uznania, zgodnie z własnym sumieniem i własnymi zapatrywaniami, niemniej jednak w sytuacjach wyraźnie przez ustawę wskazanych decyzyjność rodziców pozostaje ograniczona, o ile nie wyłączona. Stanowisko to można opisowo ujać w ten sposób, że ustawodawca wie lepiej, jak realizować zasadę dobra dziecka, i nie pozostawia rodzicom prawa decyzji w tym zakresie. Dla przykładu wskazać można administracyjnoprawne konstrukcje obowiązku szkolnego czy właśnie obowiązku szczepień ochronnych ${ }^{21}$. Należy brać też pod uwagę, że często, przyjmując konstrukcję obowiązku nakładanego na rodziców, ustawodawca nie tylko realizuje dobro dziecka (i to realizuje

17 T. Sokołowski, Prawo rodzinne..., s. 123.

${ }^{18}$ Ibidem.

${ }^{19}$ M. Łączkowska, Czy istnieje prawo do "posiadania" dziecka?, w: Prawne, medyczne i psychologiczne aspekty..., s. 73; tak też Trybunał Konstytucyjny w orzeczeniu z 28 V 1997 r., sygn. K26/96, OTK ZU 1997, nr 2, poz. 19.

${ }^{20}$ Por. art. 109 k.r.o. i bogata literatura w tym zakresie. Z komentarzy: H. Dolecki, Art. 109, w: Kodeks rodzinny i opiekuńczy. Komentarz, pod red. H. Doleckiego, T. Sokołowskiego, s. 724 i n.; J. Ignatowicz, Art. 109, w: Kodeks..., s. 940 i n.

${ }_{21}$ Trzeba jednak pamiętać, że podobnie będzie w sytuacji, gdy rodzice będą postępować w sposób naruszający dobro dziecka, np. nie poddając go leczeniu, transfuzji krwi czy nie podając pożywienia odpowiednio do wieku dziecka. 
je w sposób przez siebie przyjęty), ale także realizuje bądź zabezpiecza jakiś inny interes, także społeczny ${ }^{22}$.

Problem pojawi się wówczas, gdy rodzice (przedstawiciele ustawowi) nie akceptują stanowiska ustawodawcy, twierdząc, że zasadę dobra dziecka pojmują inaczej, a założone przez ustawodawcę środki służące osiągnięciu celu postrzegają $\mathrm{w}$ istocie jako działania godzące w dobro ich dziecka ${ }^{23}$.

\title{
2. Obowiązek szczepień w świetle Ustawy z dnia 5 grudnia 2008 r. o zapobieganiu oraz zwalczaniu zakażeń i chorób zakaźnych u ludzi
}

\author{
Należy zauważyć, że zgodnie z art. 5 ust. 1 pkt 1 b) u.z.z.c.z. osoby \\ przebywające na terytorium Rzeczypospolitej Polskiej są obowiązane \\ na zasadach określonych w ustawie do poddawania się m.in. szczepie- \\ niom ochronnym ${ }^{24}$. Także treść art. 17 ust. 1 u.z.z.c.z. nie pozostawia,
}

${ }^{22}$ Przykładowo, wyeliminowanie analfabetyzmu czy zabezpieczenie zdrowia publicznego przez wyeliminowanie niebezpieczeństwa rozprzestrzeniania się chorób zakaźnych u ludzi.

${ }^{23} \mathrm{~W}$ doktrynie $\mathrm{w}$ tym zakresie pojawiają się stanowiska bardzo spolaryzowane, w świetle których "poddanie dziecka szczepieniom obowiązkowym nie jest przedmiotem swobodnego uznania rodziców", zob. M. Boratyńska, Szczepienia ochronne małoletnich a wykonywanie władzy rodzicielskiej. Uwagi na tle wyroku NSA, "Prawo i Medycyna” 2013, nr 3-4, s. 68 i n. Por. także wyrok WSA w Bydgoszczy z 29 XII 2013 r., sygn. II SA/Bd 631/13, http://orzeczenia.nsa.gov.pl (dostęp: 17 V 2017), w którym sąd zważył nawet, że "rodzice małoletniego W., odmawiając poddania dziecka szczepieniom ochronnym, pozbawiaja go konstytucyjnego prawa do ochrony zdrowia i zapobiegania chorobom szerzącym się epidemicznie". Takie ujęcie można traktować wręcz jako działanie rodziców sprzeczne z dobrem dziecka.

${ }^{24}$ Warto brać pod uwagę, że obowiązek ten nie dotyczy wyłącznie szczepień ochronnych, a pełna treść art. 5 jest następująca: „1. Osoby przebywające na terytorium Rzeczypospolitej Polskiej są obowiązane na zasadach określonych w ustawie do: 1) poddawania się: a) zabiegom sanitarnym, b) szczepieniom ochronnym, c) poekspozycyjnemu profilaktycznemu stosowaniu leków, d) badaniom sanitarno-epidemiologicznym, w tym również postępowaniu mającemu na celu pobranie lub dostarczenie materiału do tych badań, e) nadzorowi epidemiologicznemu,f) kwarantannie, g) leczeniu, h) hospitalizacji, i) izolacji; 2) zaniechania wykonywania prac, przy wykonywaniu których istnieje możliwość przeniesienia zakażenia lub choroby zakaźnej na inne osoby - jeżeli są osobami zakażonymi, chorymi na chorobę zakaźną lub nosicielami; 3) stosowania się do nakazów i zakazów organów Państwowej Inspekcji Sanitarnej służących zapobieganiu oraz zwalczaniu zakażeń i chorób zakaźnych; 4) udzielania danych i informacji: a) organom Państwowej Inspekcji Sanitarnej, Wojskowej Inspekcji 
w tym kontekście, wątpliwości co do charakteru obowiązku. Przepis ten stanowi bowiem, że osoby, określone na podstawie ust. 10 pkt 2 u.z.z.c.z., są obowiązane do poddawania się szczepieniom ochronnym przeciw chorobom zakaźnym określonym na podstawie ust. 10 pkt 1 u.z.z.c.z., zwanym dalej "obowiązkowymi szczepieniami ochronnymi”. Interesująca pozostaje $\mathrm{w}$ zakresie prowadzonych analiz sytuacja małoletniego, którego poddaje się szczepieniom ochronnym. Ustawodawca przyjmuje bowiem, że w przypadku osoby nieposiadającej pełnej zdolności do czynności prawnych odpowiedzialność za wypełnienie obowiązków, o których mowa w art. 5 ust. 1 u.z.z.c.z., ponosi osoba sprawująca prawną pieczę nad osobą małoletnią lub bezradną albo opiekun faktyczny w rozumieniu art. 3 ust. 1 pkt 1 ustawy o prawach pacjenta i Rzeczniku Praw Pacjenta ${ }^{25}$.

W literaturze przyjmuje się w tym zakresie konstrukcję aktu osobowego, jakim jest decyzja w przedmiocie poddania się bądź poddania innej osoby, w tym w szczególności dziecka, obowiązkowym szczepieniom ochronnym. Przepis art. 5 ust. 1 pkt 2 u.z.z.c.z. w zw. z art. 17 ust. 1 u.z.z.c.z. nakłada bowiem na wszystkie osoby przebywające na terytorium państwa obowiązek poddania się szczepieniom ochronnym w ramach tzw. „Narodowego Programu Szczepień Ochronnych"26. Celowe wydaje się także zwrócenie uwagi na to, że źródłem obowiązku pozostaje przepis ustawy, nie zaś „Narodowy Program Szczepień Ochronnych"27. Jest to zatem obowiązek wynikający z ustawy.

Sanitarnej, Państwowej Inspekcji Sanitarnej Ministerstwa Spraw Wewnętrznych i Administracji, Inspekcji Weterynaryjnej, Wojskowej Inspekcji Weterynaryjnej, Inspekcji Ochrony Środowiska, jednostkom, o których mowa w art. 30 ust. 1, oraz ośrodkom referencyjnym i instytutom badawczym - niezbędnych do prowadzenia nadzoru epidemiologicznego nad zakażeniami i chorobami zakaźnymi i zapobiegania oraz zwalczania zakażeń i chorób zakaźnych, b) właściwym państwowym inspektorom sanitarnym - niezbędnych do prowadzenia nadzoru epidemiologicznego nad niepożądanymi odczynami poszczepiennymi, c) organom Państwowej Inspekcji Sanitarnej - niezbędnych do sprawowania nadzoru nad realizacją obowiązków, o których mowa w pkt 1-3.2. W przypadku osoby nieposiadającej pełnej zdolności do czynności prawnych odpowiedzialność za wypełnienie obowiązków, o których mowa w ust. 1, ponosi osoba, która sprawuje prawną pieczę nad osobą małoletnią lub bezradna, albo opiekun faktyczny w rozumieniu art. 3 ust. 1 pkt 1 Ustawy z dnia 6 XI 2008 r. o prawach pacjenta i Rzeczniku Praw Pacjenta [...]".

${ }^{25}$ Ustawa z dnia 6 XI 2008 r. o prawach pacjenta i Rzeczniku Praw Pacjenta (tekst jedn. Dz.U. 2016, poz. 186 ze zm.), dalej „u.p.p.”.

${ }^{26}$ M. Janik, Policja sanitarna, Warszawa 2012, wersja LEX/el.

27 Ibidem. 
Konstrukcję obowiązku wzmacnia także dyspozycja z art. 51 pkt 3 u.z.z.c.z. oraz art. $115 \S 1$ i 2 Kodeksu wykroczeńn ${ }^{28}$. W świetle pierwszego z powołanych przepisów podlega karze grzywny ten, kto wbrew obowiązkowi nie zawiadamia pacjenta lub osoby sprawującej prawną pieczę nad osobą małoletnią lub bezradną albo opiekuna faktycznego $\mathrm{w}$ rozumieniu art. 3 ust. 1 pkt 1 u.p.p. o obowiązku poddania się obowiązkowym szczepieniom ochronnym lub nie informuje o ochronnych szczepieniach zalecanych ${ }^{29}$. Przepis ten zabezpiecza wykonanie obowiązków zawodowych nałożonych na podmioty, na których ciąży obowiązek informacyjny. Jednocześnie zabezpieczenie realizacji celu odbywa się także w drodze egzekucji administracyjnej. Ustawodawca przyjmuje $\mathrm{w}$ tym zakresie rozwiązanie nakładające na podmioty zobowiązane do poddania się obowiązkowym szczepieniom sankcje przewidziane w Kodeksie wykroczeń ${ }^{30}$. W świetle art. $115 \S 1$ k.w. kto, pomimo zastosowania środków egzekucji administracyjnej, nie poddaje się obowiązkowemu szczepieniu ochronnemu przeciwko gruźlicy lub innej chorobie zakaźnej albo obowiązkowemu badaniu stanu zdrowia, mającemu na celu wykrycie lub leczenie gruźlicy, choroby wenerycznej lub innej choroby zakaźnej, podlega karze grzywny do 1500 złotych albo karze nagany. W świetle $\S 2$ cytowanego przepisu tej samej karze podlega, kto, sprawując pieczę nad osobą małoletnią lub bezradna, pomimo zastosowania środków egzekucji administracyjnej, nie poddaje jej określonemu w $\S 1$ szczepieniu ochronnemu lub badaniu ${ }^{31}$.

${ }^{28}$ Ustawa z dnia 20 V 1971 r. - Kodeks wykroczeń (tekst jedn. Dz.U. 2015, poz. 1094 ze zm.), dalej „k.w.".

${ }^{29} \mathrm{~J}$. Haberko, O potrzebie formalnego wyodrębnienia medycyny podróży, "Hygeia Public Health" 2013, nr 48(3), s. 249-254.

${ }^{30} \mathrm{~W}$ tym kontekście zob. np. J. Kosonoga-Zygmunt, Glosa do wyroku Sądu Najwyższego $z$ dnia 8 stycznia 2016 r., sygn. V KK 306/15, „Prokuratura i Prawo” 2016, nr 11, s. 170-181.

${ }^{31}$ Stanowisko to potwierdza Sąd Najwyższy (SN) w wyroku z 8 I 2016 r., sygn. KK 306/15, LEX nr 1963649, w którym trafnie zauważa, że jednym ze znamion wykroczenia $\mathrm{z}$ art. $115 \S 2$ k.w. w zw. z art. $115 \S 1$ k.w. jest uprzednie nieskuteczne zastosowanie środków egzekucji administracyjnej w celu wykonania ciążącego na sprawcy obowiązku poddania osoby małoletniej obowiązkowemu szczepieniu ochronnemu. Dalej sąd przyjmuje, że obowiązek rodziców poddania dziecka obowiązkowym szczepieniom ochronnym jest obowiązkiem prawnym, od którego uwolnić mogą jedynie konkretne przeciwwskazania lekarskie do szczepienia. Z art. 5 ust. 1 ustawy z 2008 r. o zapobieganiu oraz zwalczaniu zakażeń i chorób zakaźnych u ludzi wynika wprost, że osoby przebywające na terytorium kraju są obowiązane, na zasadach określonych w tej ustawie, do poddania się szczepieniom ochronnym. Ponadto, w ocenie SN, obowiązek poddania małoletniego obowiązkowym szczepieniom ochronnym wynika z mocy przepisów ustawowych. Brak jest zatem podstawy prawnej do jego konkretyzacji w formie 
Ustawa opiera się na założeniu obowiązkowości szczepień ochronnych w przypadku chorób, które na podstawie wiedzy medycznej oraz doświadczenia życiowego zostaną uznane za szczególnie groźne. Konstrukcja przyjęta w art. 17 ust. 10 u.z.z.c.z. przekazuje kompetencję do wskazania katalogu chorób ministrowi właściwemu do spraw zdrowia. Obecnie katalog ten opiera się na Rozporządzeniu Ministra Zdrowia z dnia 18 sierpnia 2011 r. w sprawie obowiązkowych szczepień ochronnych ${ }^{32}$. Minister zdrowia przyjmuje, że obowiązkiem szczepień ochronnych są objęte następujące choroby zakaźne:

1) błonica,

2) gruźlica,

3) inwazyjne zakażenie Haemophilus influenzae typu b,

4) inwazyjne zakażenia Streptococcus pneumoniae,

5) krztusiec,

6) nagminne zakażenie przyusznic (świnka),

7) odra,

8) ospa wietrzna,

9) ostre zapalenie rogów przednich rdzenia kręgowego (choroba Heinego-Medina),

10) różyczka,

11) tężec,

12) wirusowe zapalenie wątroby typu $B$,

13) wścieklizna.

Określone w $\S 3$ rozporządzenia przedziały wiekowe pozwalają stwierdzić, że obowiązkiem szczepień ochronnych obejmuje się zwłaszcza dzieci małoletnie. Wyjątek w tym zakresie mogą stanowić takie choroby, jak np. krztusiec, nagminne zakażenie przyusznic (świnka) czy odra $^{33}$. W przypadku wyżej wymienionych chorób obowiązkiem

decyzji administracyjnej. I wreszcie wynikający z przepisów obowiązek poddania dziecka szczepieniu ochronnemu jest bezpośrednio wykonalny. Jego niedochowanie aktualizuje obowiązek wszczęcia postępowania egzekucyjnego, którego zamierzonym rezultatem ma być poddanie dziecka szczepieniu ochronnemu. Zaniechanie poddania się obowiązkowemu szczepieniu mimo zastosowania środków egzekucji administracyjnej rodzi odpowiedzialność karnoadministracyjną przewidzianą w art. $115 \S 1$ k.w. Tej samej odpowiedzialności podlega też ten, kto sprawując pieczę nad osobą małoletnią lub bezradna, pomimo zastosowania środków egzekucji administracyjnej, nie poddaje jej określonemu szczepieniu ochronnemu (art. $115 \S 2$ k.w.).

${ }^{32}$ Rozporządzenie Ministra Zdrowia z dnia 18 VIII 2011 r. w sprawie obowiązkowych szczepień ochronnych (Dz.U. 2011 Nr 182, poz. 1086 ze zm.).

${ }^{33}$ Dotyczy to też innych chorób niż przykładowo wskazane w tekście. Zob. § 3 rozporządzenia z dnia 18 VIII 2011 r. w sprawie obowiązkowych szczepień ochronnych. 
obejmuje się odpowiednio: dzieci i młodzież od 7. tygodnia życia do ukończenia 19. roku życia w przypadku krztuśca; dzieci i młodzież od 13. miesiąca życia do ukończenia 19. roku życia w przypadku świnki; dzieci i młodzież od 13. miesiąca życia do ukończenia 19. roku życia w przypadku odry. Fakt, że obowiązek szczepienia obejmuje w przypadkach wskazanych chorób osoby już po uzyskaniu pełnoletności, nie będzie oczywiście rodził wątpliwości związanych z wykonywaniem władzy rodzicielskiej przez przedstawiciela ustawowego. Osoby te będą zobowiązane do poddania się szczepieniom ochronnym bez konieczności sięgania do przepisu art. 5 ust. 2 u.z.z.c.z.

Jak się wydaje, problem w tym zakresie jest jednak tylko pozorny, gdyż szczepienia są wykonywane zgodnie z Programem Szczepień Ochronnych na dany rok, ogłaszanym przez Głównego Inspektora Sanitarnego w formie komunikatu, o którym mowa w art. 17 ust. 11 u.z.z.c.z. ${ }^{34}$ Główny Inspektor Sanitarny, ogłaszając Program Szczepień Ochronnych na dany rok, podaje szczegółowe wskazania dotyczące stosowania poszczególnych szczepionek. Jednocześnie uwzględnia on aktualną sytuację epidemiologiczną. To pozwala reagować na potrzeby, nie dopuszczając do tego, by osoby, na których ciąży obowiązek poddania się szczepieniu, czekały z wykonaniem tego obowiązku "do ostatniej chwili".

\section{Procedura wykonania szczepienia}

Wykonanie obowiązkowych szczepień jako procedura będąca udzieleniem świadczenia zdrowotnego $w$ rozumieniu art. 2 ust. 1 pkt 10 ustawy o działalności leczniczej ${ }^{35}$ wymaga zachowania zasad rządzących udzielaniem świadczeń zdrowotnych ${ }^{36}$. Problem, który pojawia się w związku z wykonaniem szczepień, sprowadza się, jak można sądzić, do błędnego pojmowania istoty procedury. $\mathrm{W}$ świetle art. 17 ust. 2 u.z.z.c.z. wykonanie obowiązkowego szczepienia ochronnego jest poprzedzone lekar-

\footnotetext{
${ }^{34}$ Por. Komunikat Głównego Inspektora Sanitarnego z dnia 4 I 2017 r. w sprawie Programu Szczepień Ochronnych na rok 2017 (Dz.Urz. Ministra Zdrowia 2017, poz. 1).

${ }^{35}$ Ustawa z dnia 15 XI 2011 r. o działalności leczniczej (tekst jedn. Dz.U. 2016, poz. 1638 ze zm.).

${ }^{36} \mathrm{~W}$ świetle tego przepisu świadczeniem zdrowotnym są działania służące zachowaniu, ratowaniu, przywracaniu lub poprawie zdrowia oraz inne działania medyczne wynikające z procesu leczenia lub przepisów odrębnych regulujących zasady ich wykonywania.
} 
skim badaniem kwalifikacyjnym w celu wykluczenia przeciwwskazań do wykonania obowiązkowego szczepienia ochronnego.

W świetle zasad rządzących współczesnym prawem medycznym nie pozostaje sporne to, że lekarz powinien uzyskać zgodę na każde działanie w stosunku do pacjenta. Wyjątki w tym zakresie pozostają wyraźnie określone w przepisach szczególnych. Podjęcie działań przez lekarza uzależnione jest zatem od pozyskania zgody pacjenta ${ }^{37}$. Przepisy polskiego prawa nie pozostawiają wątpliwości co do tego, że wola pacjenta stanowić powinna w stosunku do profesjonalnej decyzji lekarza wartość wyżej cenioną ${ }^{38}$.

Lekarz, podejmując działania w stosunku do pacjenta, nie ma zatem uprawnienia do podejmowania jakichkolwiek działań, nawet jeżeli w świetle wiedzy medycznej mogą one znaleźć zastosowanie. Ma obowiązek rozważenia ryzyka, a w konsekwencji obowiązek podejmowania takich czynności, które maksymalizują korzyści

${ }^{37}$ Por. także art. 15 Kodeksu etyki lekarskiej (Kodeks etyki lekarskiej przyjęty podczas Nadzwyczajnego II Krajowego Zjazdu Izb Lekarskich odbywającego się w 1991 r., znowelizowany w 1993 r. na III Krajowym Zjeździe Lekarzy oraz w 2003 r. na Nadzwyczajnym VII Krajowym Zjeździe Lekarzy, http://www.nil.org.pl/_data/assets/pdf_ file/0003/4764/Kodeks-Etyki-Lekarskiej.pdf, dostęp: 19 V 2017, dalej „k.e.l.”), w świetle którego postępowanie diagnostyczne, lecznicze i zapobiegawcze wymaga zgody pacjenta. Jeżeli pacjent nie jest zdolny do świadomego wyrażenia zgody, powinien ją wyrazić jego przedstawiciel ustawowy lub osoba faktycznie opiekująca się pacjentem (ust. 1). W przypadku osoby małoletniej lekarz powinien starać się uzyskać także jej zgodę, o ile jest ona zdolna do świadomego wyrażenia tej zgody (ust. 2). Wszczęcie postępowania diagnostycznego, leczniczego i zapobiegawczego bez zgody pacjenta może być dopuszczone tylko wyjątkowo, w szczególnych przypadkach zagrożenia życia lub zdrowia pacjenta lub innych osób (ust. 3). Badanie bez wymaganej zgody pacjenta lekarz może przeprowadzić również na zlecenie organu lub instytucji upoważnionej do tego z mocy prawa, o ile nie stwarza ono nadmiernego ryzyka zdrowotnego dla pacjenta (ust. 4). W razie nieuzyskania zgody na proponowane postępowanie lekarz powinien nadal, w miarę możliwości, otaczać pacjenta opieką lekarską (ust. 5). Art. 13 ust. 1 k.e.l. stanowi dalej, że obowiązkiem lekarza jest respektowanie prawa pacjenta do świadomego udziału w podejmowaniu decyzji dotyczących jego zdrowia.

${ }^{38}$ Naruszenie obowiązku uzyskania przez lekarza zgody na podjęcie działań leczniczych wyczerpuje również znamiona przestępstwa opisanego w art. 192 Kodeksu karnego (Ustawa z dnia 6 VI 1997 r. - Kodeks karny, tekst jedn. Dz.U. 2016, poz. 1137 ze zm., dalej "k.k."). Zagadnienie obowiązku uzyskania zgody było przedmiotem wcześniejszych wypowiedzi. Z wielu prac zob. np.: J. Haberko, Analiza prawna i postulaty zmiany Formularzy świadomej zgody pacjentki na leczenie operacyjne, "Prawo i Medycyna” 2006, nr 24, passim; eadem, Sprzeciwy pro futuro. Problemy stosowania prawa ze szczególnym uwzględnieniem sytuacji przymusowych, w: Praktyczne problemy prawa medycznego, pod red. M. Urbaniak, Poznań 2015, passim. 
i minimalizują krzywdy, co więcej, objęte są zgodą pacjenta lub jego przedstawiciela ustawowego. Zasada ta realizuje się poprzez wymóg szczególnie starannego ważenia ryzyka i korzyści, których pacjent może doświadczyć w wyniku podjęcia działań bądź ich zaniechania. Ponadto ocena staranności po stronie podmiotu profesjonalnego, którym jest lekarz, obejmować będzie również ocenę kwalifikacji zawodowych lekarza oraz fakt zgodności realizacji określonej procedury medycznej ze standardami wykonywania tejże procedury. Wskazać też należy, że lekarzowi zakazuje się rozmyślnego krzywdzenia innych osób. Ten aspekt podejmowania działania w stosunku do pacjenta będzie miał szczególne znaczenie w przypadku pacjenta niezdolnego do samodzielnego decydowania o sobie. Powyższa zasada łączy się bowiem, jak trafnie zauważa się w literaturze, z obowiązkiem ochrony osób niezdolnych do samodzielnego decydowania o swoim życiu ${ }^{39}$. W tym kontekście celowe wydaje się także zwrócenie uwagi na tzw. zasadę sprawiedliwości w zakresie udzielania świadczeń zdrowotnych. Oznacza ona moralny obowiązek traktowania każdego człowieka w sposób właściwy, zgodnie z tym, co jest mu należne. Można zaakceptować pogląd, że zasada ta odnosi się głównie do tzw. sprawiedliwości dystrybutywnej, która wymaga, aby ciężary i korzyści wynikające $z$ udziału w procedurze medycznej były równo rozłożone. Zasada ta realizuje się m.in. poprzez obowiązek szczególnej ochrony osób niezdolnych do samostanowienia oraz osób, które ze względu na swoją sytuację zdrowotną lub życiową nie mogą samodzielnie zadbać o swoje interesy ${ }^{40}$.

W tym miejscu należy rozważyć, czy w istocie przepisy analizowanej ustawy, z której wywodzi się obowiązek szczepień, mogłyby wprowadzać w tym zakresie wyjątki na rzecz działania bez zgody. Takie rozwiązanie, jak się wydaje, może budzić wątpliwości zwłaszcza w kontekście art. 15 u.p.p. Przepis ten stanowi bowiem, że wymagana jest zgoda pacjenta lub innego uprawnionego podmiotu na udzielenie świadczeń zdrowotnych, jeżeli przepisy innych ustaw nie stanowią inaczej. Pozostaje zatem określić, czy przepisy innych ustaw - a w interesującym nas

${ }^{39}$ A. Dudzińska, Zgoda na działanie medyczne, „Państwo i Prawo” 2009, z. 11, s. 70; M. Świderska, Zgoda pacjenta na zabieg medyczny, Toruń 2007; J. Bujny, Prawa pacjenta między autonomia a paternalizmem, Warszawa 2007, zwł. rozdz. 4, § 4; M. Nesterowicz, Prawo medyczne, Toruń 2016, zwł. rozdz. IV, ust. 1 i 2.

${ }^{40}$ M. Czarkowski, J. Różyńska, Świadoma zgoda na udział w eksperymencie medycznym. Poradnik dla badacza, Warszawa 2008, s. 22. 
przypadku zwłaszcza ustawy o zapobieganiu oraz zwalczaniu zakażeń i chorób zakaźnych u ludzi - nie stanowią inaczej.

Problem sprowadza się do swoistego dualizmu w zakresie procedury dokonywania szczepień. Jak zauważono, szczepienie jest poprzedzone przez badanie kwalifikacyjne. Jest to procedura medyczna, na którą gdyby przyjąć założenia ogólne - należy uzyskać zgodę uprawnionego podmiotu. Jeżeli to badanie jest elementem działań wpisanych w udzielanie świadczeń zdrowotnych, to nie ulega wątpliwości, że lekarz lub inny podmiot wskazany $\mathrm{w}$ art. 17 ust. 6 u.z.z.c.z. powinien uzyskać zgodę na przeprowadzenie tego badania. Fakt, że zgodnie z powołanym przepisem obowiązkowe szczepienia ochronne przeprowadzają lekarze lub felczerzy, pielęgniarki, położne i higienistki szkolne, posiadający kwalifikacje, określone na podstawie ust. 10 pkt 3 u.z.z.c.z., też nie pozostawia wątpliwości, że badanie to wpisuje się $\mathrm{w}$ standard wykonywania zawodu przez te podmioty.

Argument ten wzmacnia dodatkowo dyspozycja $\mathrm{z}$ art. 17 ust. 4 u.z.z.c.z., w świetle którego to przepisu po przeprowadzonym lekarskim badaniu kwalifikacyjnym lekarz wydaje zaświadczenie ze wskazaniem daty i godziny przeprowadzonego badania. Wydanie tego zaświadczenia, co nie ulega wątpliwości, może zostać zaliczone jako element wykonywania zawodu lekarza w zakresie orzecznictwa i wydawania opinii, o których mowa w art. 2 ustawy o zawodach lekarza i lekarza dentysty ${ }^{41}$. Jednocześnie należy zwrócić uwagę na to, że badanie przeprowadza się właśnie w celu wykluczenia przeciwwskazań do dokonania szczepienia. Choć ustawodawca nie wyraża tego expressis verbis w treści cytowanego przepisu, to jednak należy przyjąć, że biorąc pod uwagę zakres podmiotowy osób uprawnionych do przeprowadzenia badań kwalifikacyjnych, jak również cel ich przeprowadzenia, mowa jest o przeciwwskazaniach natury zdrowotnej u podmiotu, u którego mają zostać przeprowadzone szczepienia. Interpretację $w$ tym kierunku wzmacnia nałożony na lekarza, w art. 17 ust. 5 u.z.z.c.z., obowiązek skierowania osoby do konsultacji specjalistycznej w sytuacji, kiedy wynik badania kwalifikacyjnego daje podstawy do długotrwałego odroczenia obowiązkowego szczepienia ochronnego.

Biorąc pod uwagę powyższe, należy odnieść się do problemu wzmiankowanego wyżej dualizmu w zakresie przyjętych rozwiązań.

${ }^{41}$ Ustawa z dnia 5 XII 1996 r. o zawodach lekarza i lekarza dentysty (tekst jedn. Dz.U. 2017, poz. 125). Zob. np. L. Ogiegło, Art. 2, w: Ustawa o zawodach lekarza i lekarza dentysty. Komentarz, pod red. L. Ogiegły, Warszawa 2010, s. 7 i n. 
W dyskusji pojawiają się głosy, że w przypadku regulacji obejmującej szczepienia ochronne, zwłaszcza obowiązkowe, ustawodawca na poziomie ustawowym przyjął rozwiązania godzące $\mathrm{w}$ autonomię pacjenta, ograniczając prawo pacjenta do samostanowienia $w$ odniesieniu do świadczenia zdrowotnego, w szczególności do wyrażenia zgody na szczepienie, ale i na badanie kwalifikacyjne. Bardzo rygorystyczne stanowisko w tym zakresie nakazywałoby tę autonomię ograniczyć zarówno w odniesieniu do decyzji o przeprowadzeniu lub nieprzeprowadzeniu szczepienia, jak również o poddaniu lub niepoddaniu badaniom kwalifikacyjnym.

\section{Zakres autonomii podmiotu w kontekście obowiązkowych szczepień ochronnych}

Analiza powołanych przepisów ustawy oraz ustawy o prawach pacjenta i Rzeczniku Praw Pacjenta pozwala, w opinii autorki, na przyjęcie następującej konstrukcji odnoszącej się do charakteru prawnego i istoty obowiązkowych szczepień ochronnych. Po pierwsze, należy przyjąć, że wykonanie szczepienia ochronnego odbywa się dwuetapowo i jakkolwiek w całości pozostaje udzieleniem świadczenia zdrowotnego, to jednak nie w całości jest objęte zakresem autonomii podmiotu, którego szczepienie ma dotyczyć. Po drugie, jeżeli przepisy ustawy nie konstruują odmiennych zasad odbierania zgody na przeprowadzenie badań kwalifikacyjnych poprzedzających wykonanie szczepienia, to w świetle art. 15 u.p.p. zastosować należy reguły ogólne przewidziane w ustawie o prawach pacjenta i Rzeczniku Praw Pacjenta. Przepis ten stanowi, powtórzmy, że wymagana jest zgoda pacjenta lub innego uprawnionego podmiotu na udzielenie świadczeń zdrowotnych, jeżeli przepisy innych ustaw nie stanowią inaczej. Przepisy ustawy o zapobieganiu oraz zwalczaniu zakażeń i chorób zakaźnych u ludzi nie wprowadzaja w tym zakresie żadnych rozwiązań prócz powołanej wyżej konieczności przeprowadzenia badań kwalifikujących. Należy w tym zakresie przychylić się do wniosku, że zakresem autonomii uprawnionego podmiotu objęta pozostaje tylko jedna z części procedury obowiązkowych szczepień ochronnych.

Przyjęcie obowiązkowego charakteru szczepienia skłaniać będzie dalej do zaakceptowania stanowiska, że samo przeprowadzenie obowiązkowego szczepienia ochronnego pozostaje poza zakresem woli 
podmiotu. To, w przekonaniu autorki, oznacza, że o ile można, a nawet należy zastosować konstrukcję opartą na autonomii woli podmiotu w przypadku badania kwalifikacyjnego, o tyle zgoda, a zatem i jej odmowa, w odniesieniu do samego szczepienia, pozostają poza zakresem rozpoznania przez system prawny. Tu jednak powstaje kolejny problem interpretacyjny, który wiąże się z zakresem obowiązku informacyjnego w odniesieniu do badań kwalifikacyjnych ${ }^{42}$.

Brak wyraźnego rozstrzygnięcia ze strony ustawodawcy może skłaniać do przyjęcia stanowiska, że obowiązkiem informacyjnym objęte będa, co oczywiste, zakres i cel badań kwalifikacyjnych ${ }^{43}$. Jednak fakt, że cel jest determinowany wykonaniem szczepienia, zdaje się uzasadniać także dostarczenie informacji o rodzajach dostępnych szczepionek oraz uzasadnieniu dla wykonania szczepienia. W tym kontekście niezwykle istotne wydaje się rozstrzygnięcie o zakresie obowiązku informacyjnego na temat skutków szczepienia i możliwych konsekwencji zdrowotnych. Szczególnie doniosłe jest zaś ustalenie, czy na tym etapie osobie poddawanej szczepieniu lub jej przedstawicielowi ustawowemu należy dostarczyć informację obejmującą: ryzyko wystąpienia niepożądanego odczynu poszczepiennego i sankcji administracyjnych za niepoddanie się osobiście lub osoby pozostającej pod władzą rodzicielską szczepieniu ${ }^{44}$.

Brak rozstrzygnięcia w ustawie o zapobieganiu oraz zwalczaniu zakażeń i chorób zakaźnych u ludzi może kierować proces interpretacji do następujących, jak się wydaje, wykluczających się wniosków: po pierwsze, podejmując badania kwalifikacyjne i zakładając konieczność uzyskania na nie zgody, nie sposób nie poinformować o celu samych badań.

${ }^{42}$ Na temat obowiązku informacyjnego zob. P. Łuków, Miejsce uświadomionej zgody na postępowanie medyczne w kulturze społeczeństwa demokratycznego, w: Wybrane aspekty praw człowieka a bioetyka, pod red. A. Białek, M. Wróblewskiego, Warszawa 2016, s. 11-20; T. Sroka, Informacja o możliwych metodach diagnostyki i terapii jako przesłanka skuteczności zgody pacjenta na udzielenie świadczenia zdrowotnego, w: Wybrane aspekty..., s. 21-34.

${ }^{43}$ W tym kontekście zob. np. M. Nesterowicz, Glosa do wyroku Sądu Najwyższego z dnia 26 kwietnia 2007 r., II CSK 2/07 - obowiazek udzielenia pacjentowi informacji a brak konieczności wskazania wszystkich możliwych skutków zabiegu, w: idem, Prawo medyczne. Komentarze i glosy do orzeczeń sadowych, Warszawa 2017, s. 283 i n.; idem, Prawo medyczne, s. 181 i n.

${ }^{44}$ M. Boratyńska, op. cit., s. 68; autorka zauważa ponadto: „w przypadku szczepień obowiązkowych małoletniego zgoda przedstawiciela ustawowego nie jest wymagana, chodzi bowiem o spełnienie obowiązku. Swoboda wyboru dotyczy co najwyżej będących do dyspozycji różnych specyfików, włączając w to decyzję co do podania szczepionki skojarzonej". To stanowisko zdaje się jednak zakładać pewną sprzeczność: jeżeli pozostawia się rodzicom swobodę decyzji co do rodzaju szczepionki, to jednak pozwala się im, jak się wydaje, realizować uprawnienie wynikające z władzy rodzicielskiej. 
Włączenie do obowiązku informacyjnego informacji o ryzyku związanym nie z samymi badaniami kwalifikacyjnymi, ale ze szczepionkami, którym badania te służą, może spowodować brak zgody na badania kwalifikacyjne, co w konsekwencji zamknie możliwość ich przeprowadzenia, a tym samym możliwość dokonania szczepienia. Pamiętać należy, że chociaż uznaliśmy wcześniej, iż same badania i wyrażenie na nie zgody zostaja objęte autonomią stron, to takie rozwiązanie nie jest zgodne $z$ intencja ustawodawcy. Drugi wniosek zdaje się również nie rozstrzygać problemu. Trudno bowiem przyjąć, kierując się doświadczeniem życiowym oraz standardem wykonywania zawodu lekarza czy innego podmiotu przeprowadzającego badania kwalifikacyjne, że uzyskanie zgody na te badania odbędzie się w oderwaniu od celu, któremu one służą. Doświadczenie życiowe i zdrowy rozsądek podpowiadają bowiem, że nie sposób przeprowadzić badania kwalifikującego do wykonania szczepień, nie wspominając o samym szczepieniu. Informacja o szczepieniu musi się jednak wiązać z tym, że podmiot profesjonalny dostarczy pełnej informacji na temat samego szczepienia i skutków z nim związanych.

\section{Podsumowanie}

Reasumując powyższe rozważania, należy zauważyć, że ustawodawca nie rozstrzyga w sposób satysfakcjonujący, czy pacjent lub jego przedstawiciel ustawowy może wyrazić zgodę na przeprowadzenie badania kwalifikującego, a odmówić poddania się szczepieniu. Jak się wydaje, przeprowadzenie badań kwalifikacyjnych nie ma w takim przypadku większego sensu. Z drugiej zaś strony brakuje wyraźnego rozstrzygnięcia ustawowego, z którego wynikałoby, że odmowa przeprowadzenia szczepienia po dokonaniu badań kwalifikacyjnych pozostaje bez znaczenia, gdyż samo szczepienie nie wymaga zgody, ponieważ jest obowiązkowe.

Biorąc pod uwagę powyższe, można jedynie częściowo podzielić stanowisko Wojewódzkiego Sądu Administracyjnego w Białymstoku wyrażone w wyroku z dnia 16 kwietnia 2013 r. ${ }^{45}$ Sąd przyjął tam następujący pogląd: „ustawowy obowiązek szczepień ochronnych oznacza niedopuszczalność korzystania z tzw. klauzuli sumienia, tj. uprawnienia pacjenta do odmowy poddania się świadczeniu zdrowotnemu z powołaniem się na art. 16 ustawy z dnia 6 listopada 2008 r. o prawach pacjenta

${ }^{45}$ Wyrok WSA w Białymstoku z 16 IV 2013 r., sygn. II SA/Bk 18/13, http://orzeczenia. nsa.gov.pl (dostęp: 19 V 2017). 
i Rzeczniku Praw Pacjenta. Wynikające z wyżej wymienionej ustawy uprawnienie pacjenta do wyrażenia zgody na udzielenie świadczeń zdrowotnych albo odmowy takiej zgody jest bowiem wyłączone w przypadkach, gdy przepisy odrębne stanowią inaczej, a zatem, między innymi, w odniesieniu do szczepień ochronnych obowiązkowych z mocy ustawy o zapobieganiu oraz zwalczaniu zakażeń i chorób zakaźnych u ludzi"46. Pomijając oczywiście nietrafne powołanie instytucji klauzuli sumienia, trudno de lege lata przyjąć, że uzasadnienie powołane przez sąd znajduje oparcie w materialnoprawnych podstawach wynikających z ustawy o zapobieganiu oraz zwalczaniu zakażeń i chorób zakaźnych u ludzi. Gdyby w istocie tak miało być, należałoby oczekiwać od ustawodawcy stosownego doprecyzowania w treści przepisów.

Możliwe jest także inne uzasadnienie, które przyjął Wojewódzki Sąd Administracyjny w Warszawie w wyroku z dnia 10 lutego $2017 \mathrm{r} .{ }^{47}$ Sąd wyprowadził wniosek, że "obowiązek poddania się obowiązkowym szczepieniom ochronnym oznacza również obowiązek poddania się lekarskim badaniom kwalifikacyjnym w celu wykluczenia przeciwwskazań do wykonania obowiązkowego szczepienia ochronnego na podstawie art. 17 ust. 2 ustawy z 2008 r. o zapobieganiu oraz zwalczaniu zakażeń i chorób zakaźnych u ludzi. W związku z tym nie można skutecznie podnosić zarzutu braku wymagalności obowiązku poddania się obowiązkowym szczepieniom, wskazując na brak badania kwalifikacyjnego i prawo do odmowy poddania się temu badaniu na podstawie art. 16 ustawy o prawach pacjenta. Badanie takie może być wykonane bezpośrednio przed wykonaniem szczepienia, zaś odmowa poddania się temu badaniu, która $\mathrm{w}$ konsekwencji uniemożliwia wykonanie szczepienia, jest $\mathrm{w}$ istocie odmową poddania się obowiązkowemu szczepieniu ochronnemu, któremu nie można przeciwdziałać, wykorzystując art. 16 ustawy o prawach pacjenta" ${ }^{\prime \prime 8}$. Tego rodzaju uzasadnienie pozwala osiągnąć zamierzony cel. Jak się jednak wydaje, de lege lata brak jest wyraźnego oparcia w przepisach ustawy o zapobieganiu oraz zwalczaniu zakażeń i chorób zakaźnych u ludzi, z którego wynikałoby, że w istocie przepisy art. 16 u.p.p. nie znajdą zastosowania, gdyż przepisy innych ustaw stanowią inaczej.

Formułując wnioski końcowe, trzeba $\mathrm{z}$ całą mocą podkreślić, że de lege ferenda oczekiwać należy od ustawodawcy wyraźnego rozstrzygnięcia w zakresie wyłączenia uprawnienia do wyrażenia zgody bądź jej

\footnotetext{
${ }^{46}$ Wyrok WSA w Białymstoku z 16 IV 2013 r., sygn. II SA/Bk 18/13..

${ }^{47}$ Wyrok WSA w Warszawie z 10 II 2017 r., sygn. VII SA/Wa 819/16, LEX nr 2252052.

${ }^{48}$ Wyrok WSA w Warszawie z 10 II 2017 r., sygn. VII SA/Wa 819/16.
} 
odmowy w sytuacji badania poprzedzającego udzielenie świadczenia, które na podstawie odrębnych przepisów jest obowiązkowe. Przyjąć można, że albo nie wymaga się zgody zarówno na badania kwalifikacyjne, jak i na szczepienie, albo zakresem autonomii - niezależnie od stanowiska wyrażonego w zgodzie na badania - nie obejmuje się samych szczepień. Ustawodawca musiałby rozważyć w tej sytuacji, jakie będą konsekwencje, jeżeli podmiot uprawniony do wyrażenia zgody na badanie kwalifikacyjne zgody tej odmówi. Jak się wydaje, osiągnięcie celu zgodnego z zamierzeniem ustawodawcy możliwe będzie jedynie w razie przyjęcia, że zarówno badanie kwalifikacyjne, jak i szczepienie pozostają poza zakresem autonomii jednostki. Takie stanowisko wyłączy, rzecz jasna, także możliwość decydowania o rodzaju stosowanych preparatów.

\section{MANDATORY CHILD VACCINATION AND THE CONSENT OF A STATUTORY REPRESENTATIVE FOR THE PERFORMANCE OF A QUALIFYING MEDICAL EXAMINATION}

\section{S u m mary}

The article focuses on the analysis of the parent situation (or statutory representatives) who are under legal requirement to subject their children to preventive vaccination. The main deliberations focus on answering the question of how the parents' (or statutory representatives') position should be treated if they, relying on the principle of autonomy and their parental rights, and pointing to their duty to exercise care of a minor and to represent a minor child, fail to take any action intended to implement the obligation imposed by law. Parents refer to the principle of child's welfare and argue that vaccination constitutes an essential threat to the values they recognise, such as autonomy, freedom to make decisions regarding the actual situation and legal position of a child, or the child's welfare. The issue of parents' autonomy and implementation of child's welfare is raised. Parents often bring up an argument of the harmful effects of vaccination and claim that by refusing to agree to vaccination they exercise the principle of child's welfare.

The legal character of the refusal to consent to child vaccination is also analysed. Here, deliberations are set in the context of imprecisely formulated statutory provisions and their mutual relations, especially in the context of the meeting of acts from two branches of law: administrative and civil, and within the latter family law in particular. An attempt has been made to explain doubts whether despite the mandatory requirement and resulting from it obligation threatened with an administrative fine statutory representatives still have a right to express or not consent for vaccination of their children or to decide about at any stage of the procedure.

Keywords: vaccination - obligation - statutory representative - consent 